Ristekdik (Jurnal Bimbingan dan Konseling)

Vol 6, No.1, 2021, hlm. 19-30

ISSN 2541-206X (online)

ISSN 2527-4244 (cetak)

\title{
KONSELING LOGOTERAPI SEBAGAI SOLUSI DALAM MENANGANI MASALAH PSIKOLOGIS REMAJA PUTUS SEKOLAH
}

\author{
Muhammad Fikri Haekal \\ Universitas Islam Negeri Sunan Kalijaga Yogyakarta \\ fikrihaekal1123@gmail.com
}

\begin{abstract}
This study aims to reveal how logotherapy counseling can solve the psychological problems of school dropouts. Similar to other counseling approaches in uncovering, analyzing and fostering client problems, logotherapy emphasizes more on directing clients to seek and find lessons from the problems they have experienced since the early stages of counseling. This research method uses the library research method which obtains data from books, journals, documents, magazines, and so on. The findings of this study in the form of logotherapy counseling can help teenagers who drop out of school to realize the potential and spiritual resources that have been hampered in them, which they will use to deal with various problems. Logotherapy counseling also teaches them to see the positive value of suffering which then turns it into an achievement through the attitude they take.
\end{abstract}

Keywords: logotherapy, adolescents, school dropouts

\begin{abstract}
Abstrak: Penelitian ini memiliki tujuan untuk mengungkap bagaimana konseling logoterapi bisa menyelesaikan masalah psikologis remaja putus sekolah. Sama halnya dengan pendekatan konseling yang lain dalam mengungkap, menganalisis dan membina masalah klien, namun logoterapi lebih menekankan untuk mengarahkan klien dalam mencari dan menemukan hikmah dari masalah yang dialaminya sejak tahap awal konseling. Metode penelitian ini menggunakan metode kepustakaan (library research) yang memperoleh data dari buku, jurnal, dokumen, majalah, dan lain sebagainya. Temuan penelitian ini berupa konseling logoterapi dapat membantu remaja putus sekolah dalam menyadari potensi dan sumber daya spiritual yang selama ini terhambat dalam diri mereka yang kemudian keduanya akan mereka manfaatkan untuk menghadapi berbagai macam masalah. Konseling logoterapi juga mengajarkan mereka untuk melihat nilai positif dari penderitaan yang kemudian mengubahnya menjadi sebuah prestasi melalui sikap yang mereka ambil.
\end{abstract}

Kata kunci: logoterapi, remaja, putus sekolah

\section{PENDAHULUAN}

Anak adalah investasi serta harapan bangsa yang akan menjadi penerus generasi masa depan. Masa anak-anak adalah masa dimana mereka mengalami pertumbuhan yang akan menentukan masa depannya kelak. Untuk itu optimalisasi perkembangan anak sangat dibutuhkan, dan demikian itu pula anak membutuhkan kasih sayang dari kedua orang tuanya sehingga hak dan kebutuhan bisa terpenuhi dengan baik. Seorang anak harus tumbuh menjadi pribadi yang sehat jasmani dan rohani, cerdas, terpuji, bermoral tinggi, dan bahagia. Karena di masa depan nanti mereka akan menjadi aset yang menentukan kualitas dari suatu peradaban bangsa.

Namun pada kenyataannya masih banyak anak dan remaja yang terlantar dan putus sekolah. Banyak anak dan remaja yang tidak memiliki kesempatan untuk meningkatkan 
potensi yang dimilikinya. Kebanyakan dari mereka mengalami permasalahan seperti perekonomian keluarga, kasih sayang orang tua yang tak terpenuhi, dan tidak mendapat pelayanan pendidikan yang maksimal. Putus sekolah termasuk problem pendidikan yang sangat serius, karena dengan meninggalkan sekolah maka kesejahteraan ekonomi dan sosial dari anak-anak dan remaja tersebut sangat terbatas karena tidak bisa mendapatkan pendidikan yang memadai.

Problem putus sekolah bagi seorang remaja merupakan permasalahan yang sangat serius, karena dengan adanya problem ini berarti sumber daya manusia bagi bangsa ini telah berkurang dan tidak akan sanggup menghadapi tantangan-tantangan yang ada di masa depan. Problem ini juga dapat mengancam kelangsungan hidup mereka dikarenakan tingginya angka putus sekolah yang terjadi pada generasi penerus bangsa. Hal ini akan berakibat pada tidak adanya bekal yang akan menunjang hidup mereka ketika menjadi dewasa, dan tidak tercapainya cita-cita sehingga muncul perasaan rendah diri serta terasingkan dari lingkungan sekitar mereka. (Tamba, Krisnani, \& Gutama, 2015)

Penelitian mengenai konseling logoterapi sudah dikemukakan, diantaranya adalah penelitian yang dilakukan oleh Sri Ayatina Hayati dan Aminah. Penelitian ini mengkaji dan menentukan efektifitas logoterapi dengan konseling kelompok dalam meningkatkan penerimaan diri pada anak-anak yang mengalami broken home. Temuan pada penelitian ini berupa konseling logoterapi efektif untuk meningkatkan penerimaan diri anak-anak yang mengalami broken home pada semua indikator yang meliputi: menunjukkan penerimaan dan memberikan perasaan positif, untuk berkomunikasi, mendengarkan masalah dengan pikiran yang terbuka, ketulusan, menerima keterbatasan, dukungan cinta, cinta tanpa syarat. (Hayati \& Aminah, 2020)

Penelitian lain yang dilakukan oleh Nurani Jayanti mendapatkan temuan berupa koseling logoterapi dapat membantu klien dalam menetapkan tujuan hidupnya. Klien yang berada dalam posisi yang tidak memungkinkan untuk beraktivitas dan berkreativitas serta kesukaran yang menakutkan dalam hidupnya, dibantu dengan cara menghadapi kondisi tersebut dan juga cara ia mengatasinya. Konseling logoterapi mengajarkan kepada klien bagaimana melihat kesempatan untuk bersyukur dan melihat nilai-nilai positif dari penderitaan yang sedang dialaminya. (Jayanti, 2019)

Berdasarkan penelitian terdahulu yang telah dikemukakan di atas, dapat dikatakan bahwa penelitian mengenai konseling logoterapi sudah banyak dilakukan sebelumnya. Akan tetapi belum ada penelitian konseling logoterapi yang berfokus pada remaja putus sekolah. Terlebih remaja merupakan penerus generasi bangsa harus dibekali dengan pendidikan yang memadai, sehingga mereka bisa mengembangkan kreativitas dan keterampilan yang mereka miliki dan menjadi sumber daya manusia yang berkualitas. Namun 
pada kenyataanya masih banyak anak dan remaja yang terlantar dan putus sekolah. Masih banyak anak-anak dan remaja tidak memiliki kesempattan untuk mengembangkan potensi yang dimilikinya. Dari sinilah perlu dipertanyakan bagaimana peran konseling logoterapi dalam menyelesaikan problem psikologis remaja yang mengalami putus sekolah.

\section{METODE}

Penelitian ini merupakan penelitian kepustakaan (library research) yaitu penelitian yang mendapatkan data-data bersumber dari perpustakaan baik berupa buku, ensklopedi, kamus, jurnal, dokumen, majalah dan lain sebagainya. Referensi menjadi sumber utama dalam penulisan artikel ini. Sehingga penulis mengumpulkan data-data melalui referensi yang telah dikumpulkan dan ditulis pada literatur review penelitian ini.

\section{HASIL}

Terdapat tiga poin utama yang akan dibahas pada penelitian ini yaitu meliputi:

\section{Remaja Putus Sekolah}

Kata remaja berasal dari bahasa latin "adolescence" (kata bendanya adalah adolescentia yang berarti remaja) yang memiliki arti tumbuh atau tumbuh menjadi dewasa. Istilah kata adolescence mempunyai artian yang lebih luas mencakup kematangan mental, emosional, sosial, dan fisik. Masa remaja merupakan masa transisi dari masa anak-anak menuju dewasa yang akan diikuti oleh berbagai masalah yang ada dikarenakan perubahan fisik, psikis, dan sosial. Masa peralihat tersebut banyak menimbulkan kesulitan dalam penyesuaian dalam dirinya maupun lingkungan sosial. Hal ini disebabkan karena remaja merasa bukan termasuk anakanak lagi tetapi juga belum termasuk orang dewasa dan remaja ingin diperlakukan sebagai orang dewasa. (B. Hurlock, n.d.)

Erikson berpendapat bahwa masa remaja adalah tahap pencarian identitas diri dengan adanya beberapa tugas perkembangan yang harus tercapai dengan baik. Jika remaja tersebut gagal dalam melaksanakan tugas perkembangannya maka akan berpengaruh terhadap tahap perkembangan berikutnya. Tugas-tugas perkembangan tersebut antara lain pencapaian hubungan yang lebih matang dengan teman sebaya dan pencarian peran sosial antara laki-laki dan perempuan, kemandirian emosional, tanggung jawab, persiapan karir dan keluarga, dan lain sebagainya. (Trisnawati, Nauli, \& Agrina -, 2014)

Menurut Soekanto masa remaja terbagi menjadi empat bagian yaitu pra remaja (10-12 tahun), masa remaja awal (12-15 tahun), masa remaja pertengahan (15-18 tahun), dan masa remaja akhir (18-21 tahun). Sementara menurut Hurlock masa remaja dapat dikelompokkan menjadi dua yaitu masa remaja awal pada rentang usia 13 atau 14 tahun sampai 17 tahun, dan masa remaja akhir yaitu pada rentang usia 17 sampai 21 tahun. Sedangkan menurut Andi Mappiare masa remaja berlangsung pada usia 
12-21 tahun bagi perempuan dan usia 13-22 tahun bagi laki-laki. Pada rentang usia yang disebutkan diatas dapat dibagi menjadi dua yaitu remaja awal ketika usia 12/13 tahun sampai dengan 17/18 tahun dan remaja akhir ketika usia 17/18 tahun sampai dengan 21/22 tahun. (Albanjari, 2018)

Berdasarkan penjelasan yang telah dikemukakan diatas dapat kita tarik kesimpulan bahwa masa remaja merupakan peralihan dari masa anak-anak menujur masa dewasa yang ditandai dengan perubahan fisik, perubahan kognitif, dan perubahan sosial pada rentang usia 12-21 tahun yang di bagi menjadi tiga fase yaitu fase awal, fase pertengahan, dan fase akhir.

Putus sekolah dapat didefinisikan sebagai Drop Out (DO) yaitu seorang anak didik yang keluar dan tidak masuk lagi untuk sekolah selama-lamanya disebabkan oleh berbagai hal seperti malas, malu, takut, maupun sekedar ikut-ikutan temannya. Remaja yang mengalami putus sekolah biasanya tidak bisa memperkirakan perbuatan yang mereka lakukan, akibatnya mereka cenderung rentan terhadap resiko apabila tidak diberikan bantuan berupa dukungan sehingga bisa meningkatkan ketahanan serta kemampuannya dengan cara memberikan pilihan hidup yang positif. (Huruswati, 2017)

Penyebab putus sekolah bukan hanya berasal dari dalam diri anak didik itu sendiri, tetapi juga bisa berasal dari luar diri anak didik tersebut seperti tidak adanya biaya dan sarana pendidikan. Seperti yang diungkapkan oleh
Bahruddin $\mathrm{M}$ bahwa faktor penyebab putus sekolah adalah faktor kependudukan, faktor ledakan usia sekolah, faktor biaya, faktor kemiskinan, faktor sarana, faktor sistem pendidikan, faktor IQ (Intelegensi), faktor mentalitet anak didik. (Tamba et al., 2015)

Dari faktor yang menyebabkan putus sekolah di atas, bisa kita lihat bahwa penyebab putus sekolah bukanlah hal yang sederhana melainkan banyak faktor yang telah menyebabkannya. Berdasarkan pengertian remaja putus sekolah diatas, bisa kita artikan bahwa yang menjadi yang menjadi inti permasalahan remaja putus sekolah adalah ketidakmampuan, baik itu ketidakmampuan dari diri anak didik maupun dari luar diri anak didik.

\section{Kondisi Psikologis Remaja Putus Sekolah}

Berdasarkan penelitian yang telah dilakukan oleh Hening Riyadiningsih dan Ratna Puji Astuti menunjukkan bahwa anak putus sekolah memiliki kecenderungan external locus of control. Ketika individu mengalami external locus of control maka ia menjadi pasrah terhadap nasib dan keadaan yang ada disekitarnya tanpa adanya keinginan untuk mengubah keadaan tersebut. Individu yang mengalami external locus of control juga cenderung menyandarkan harapannya kepada orang lain, sehingga membuat dirinya menjadi sangat tergantung kepada orang lain, dan mereka cenderung lebih memilih dan mencari situasi yang menguntungkan mereka. (Riyadiningsih \& Astuti, 2013) 


\section{Konseling Logoterapi}

Asal kata logoterapi berasal dari bahasa Yunani yaitu kata "logos" yang mempunyai konotasi "makna" dan "jiwa". Logoterapi bermaksud untuk membantu klien dalam mencari makna. Oleh karena itu usaha yang paling utama dalam konseling logoterapi adalah membantu klien dalam menemukan makna hidupnya dengan cara menolong klien dalam mengatasi masalah neurosis yang sedang dialaminya. (Jayanti, 2019)

Konseling logoterapi menekankan pada aspek pengarahan klien untuk menemukan hikmah dari masalah yang sedang dihadapinya sejak tahap awal konseling dan tidak berfokus pada katarsis atau asosiasi bebas klien dalam menyampaikan masalahnya. Dalam pendekatan ini klien terlibat dalam hal pembukaan diri. Dengan terbukanya pintu yang tertutup maka klien akan mampu membuka belenggu deterministik yang selama ini menyebabkan klien terpenjara. Jadi fungsi konselor pada logoterapi adalah mengungkapkan bahwa klien mampu menemukan makna bahkan dalam sebuah penderitaan, dan bukanlah menyampaikan apa makna hidup yang harus ia ciptakan. Melalui sikap yang diambil klien dalam menghadapi penderitaanya maka penderitaan tersebut bisa diubah menjadi sebuah prestasi. (Jayanti, 2019)

\section{a. Sejarah Logoterapi}

Konseling logoterapi diciptakan oleh Viktor Emil Frankl. Dia dilahirkan pada tanggal 26 Maret tahun 1905 di Wina, Austria. Merupaka anak kedua yang terlahir sebagai keluarga yahudi dari pasangan Gabriel Frankl dan Elsa Frankl. Dalam diri Frankl, nilai-nilai spiritual Yudaisme sangat bepengaruh kuat khususnya mengenai makna hidup. Frankl menempuh sebagian besar hidup dan pendidikan mulai dari pendidikan dasar sampai pendidikan yang tinggi di tengah suasana kehidupan keluarganya yang sangat memperhatikan hal-hal keagamaan. (Ketut Sri Diniari, 2017)

Frankl berasal dari kota Vienna, Austria dan dia merupakan seorang Professor di bidang neurologi dan psikiatri di University of Vienna Medical School serta merupakan guru besar luarbiasa di bidang logoterapi pada U.S. International University. Frankl adalah pendiri dari aliran logoterapi yang disebut sebagai mazhab ketiga psikoterapi dari Wina setelah psikoanalisis Sigmund Freud dan psikologi individu Alfred Adler. (Ketut Sri Diniari, 2017)

Pada tahun 1942 hingga 1945 Frankl dijadikan tawanan di kamp konsentrasi maut Jerman. Ketika itu orang tuanya, sudara lakilakinya serta istri dan anak-anaknya telah meninggal. Pengalaman mengerikan tersebut selalu melekat dalam ingatannya, akan tetapi dia tidak mau kenangan itu menghilangkan gairah dan rasa cintanya untuk hidup, jadi kenangan tersebut dia gunakan secara konstruktif. (Ketut Sri Diniari, 2017)

Frankl menyaksikan dan mengalami para tahanan diteror, disiksa, dan dibunuh secara kejam di kamp Jerman tersebut. Frankl mencoba meringankan penderitaan yang dirasakan sesama tahanan dengan cara 
membesarkan hati para mereka yang sedang putus asa serta membantu menunjukkan bahwa terdapat hikmah bahkan dalam sebuah penderitaan sekalipun. Dia melihat bahwa para tahanan yang tetap menunjukkan ketabahan dalam dirinya serta mampu bertahan adalah mereka yang berhasil mengembangkan diri mereka tentang harapan dan kebebasan. Mereka yang berhasil menemukan dan mengembangkan makna dari penderitaan yang dialami (meaning in suffering) adalah mereka yang masih memiliki harapan dan meyakini akan adanya pertolongan melalui perbuatan kebajikan. Frankl telah belajar banyak mengenai makna hidup dan yang lebih spesifik lagi adalah makna penderitaan. (Ketut Sri Diniari, 2017)

Ketika perang dunia kedua telah berakhir dan para tawanan yang tersisa dibebaskan, Frankl Kembali ke kota tempat ia lahir dan menjadi kepala bagian neurologi dan psikiatri di Poliklinik Hospital dan Kembali mengajar di University of Vienna Medical School. Kemudian ia menyebarkan pandangannya mengenai logoterapi melalui buku-buku, artikel, maupun ceramah-ceramahnya. Frankl juga aktif sebagai dosen tamu atau pembicara dalam bidang logoterapi dengan melakukan kunjungan di berbagai universitas di seluruh dunia. (Ketut Sri Diniari, 2017) Viktor Emil Frankl meninggal pada tanggal 2 September tahun 1997. (Wahyuni, 2018)

\section{b. Tujuan Logoterapi}

Logoterapi memiki tujuan utama yaitu meraih hidup yang bermakna serta mampu mengatasi berbagai kendala dan hambatan pribadi secara efektif. Semua itu didapatkan dengan cara menyadari dan memahami serta merealisasikan berbagai potensi dan sumber daya spiritual yang dimiliki oleh setiap orang yang mungkin selama ini masih terhambat dan terabaikan. Jadi tugas utama orang tersebut adalah menemukan potensi dan sumber daya spiritual miliknya jika dia masih belum menemukannya. Tujuan dari konseling logoterapi dapat ditulis sebagai berikut: (Ketut Sri Diniari, 2017)

1) Agar individu memahami bahwa adanya potensi dan sumber daya spiritual yang secara universal ada dalam diri setiap orang terlepas dari ras, keyakinan, maupun agama yang dianutnya.

2) Agar individu menyadari bahwa potensi dan sumber daya spiritual tersebut sering ditekan, terhambat, diabaikan, atau bahkan terlupakan.

3) Agar individu memanfaatkan kedua hal tersebut untuk kembali bangkit dari penderitaan dan mampu tegak dan kokoh dalam menghadapi berbagai masalah dan secara sadar mengembangkan diri dalam meraih hidup yang bermakna.

\section{c. Pandangan Logoterapi Terhadap Manusia}

Manusia dalam logoterapi dipandang sebagai makhluk yang bebas dan berdasarkan keinginannya dalam mewujudkan makna maka manusia akan mengubah kehidupannya sesuai dengan keinginannya menjadi kenyataan. Makna hidup merupakan hal yang berharga dan memiliki nilai khusus bagi kehidupan 
seseorang. Makna hidup terkait dengan alasan dan tujuan dari kehidupan seseorang itu sendiri. (Ketut Sri Diniari, 2017)

Menurut Frankl dan Koeswara makna hidup bukanlah suatu hal yang bisa didapatkan dari hasil pemikiran idealistik dan hasrat-hasrat atau naluri manusia. Tetapi makna hidup itu bersifat objektif dan berada di luar dari diri manusia. Karena makna hidup menentang manusia untuk dapat meraihnya. (Ketut Sri Diniari, 2017)

\section{d. Pandangan Logoterapi Terhadap Masalah}

Menurut pandangan logoterapi, masalah akan mucul ketika individu kehilangan makna hidupnya atau ketidakmampuan individu tersebut dalam mengambil hikmah dari peristiwa yang dialaminya. Logoterapi memandang masalah sebagai ujian hidup yang harus dihadapi dengan keberanian dan kesabaran, yaitu keberanian untuk membiarkan masalah untuk sementara waktu dan kesabaran untuk tidak menyerah dan mengupayakan penyelesaian. (Pasmawati, 2015)

Pada umumnya karakteristik masalah yang disampaikan oleh klien sangat sesuai dengan pendekatan logoterapi di antaranya ditimpa musibah, tidak mampu menerima kenyataan buruk yang terjadi pada kehidupannya, tidak mampu menghadapi kegagalan, dan kesalahan dalam pengambilan keputusan. (Pasmawati, 2015)

\section{e. Konsep Dasar Logoterapi}

Pada pelaksanaannya, logoterapi memiliki tiga konsep dasar, yaitu: (Ketut Sri Diniari, 2017)

1) Pada setiap situasi hidup baik penderitaan maupun kebahagiaan pasti terdapat makna di dalamnya. Makna hidup merupakan sesuatu yang penting dan memberikan nilai khusus bagi kehidupan seseorang. Jika orang tersebut mampu menemukan dan memenuhi makna hidupnya, maka kehidupannya akan lebih berharga dan akan berakibat menimbulkan penghayatan bahagia.

2) Kebebasan dalam berkehendak. Manusia memiliki kebebasan yang tak terbatas untuk menemukan makna dalam kehidupannya. Makna hidup tersebut bisa ditemukan melalui kehidupan itu sendiri dalam karya-bakti, keyakinan atas harapan, dan kebenaran serta penghayatan atas keindahan iman dan cinta kasih.

3) Manusia memiliki kemampuan untuk mengambil sikap dari penderitaan dan peristiwa tragis yang terjadi dalam kehidupannya. Apabila peristiwa tragis tersebut tidak dapat diubah dan agar manusia tidak terhanyut dalam menghadapi keadaan tersebut, maka sebaiknya ia mengambil sikap yang tepat dalam menghadapinya. 
f. Hubungan Konselir Dan Konseli Dalam Logoterapi

Pada konseling logoterapi konseli mampu mengalami persepsi tentang dunianya secara subjektif. Selama proses terapi klien harus selalu aktif karena dialah yang harus memutuskan perasaan ketakutan, berdosa, dan kecemasan yang akan dieksplorasi. Sebab memulai proses konseling merupakan keputusan yang menakutkan. (Ketut Sri Diniari, 2017)

Konseli terlibat dalam hal pembukaan pintu diri sendiri. Dengan terbukanya pintu yang tertutup maka klien akan mampu membuka belenggu deterministik yang selama ini menyebabkan klien terpenjara secara psikologis. Lambat laun konseli akan mulai sadar, siapa dirinya tadi dan apa dia sekarang serta konseli akan lebih mampu menetapkan masa depan yang diinginkannya. Melalui terapi klien bisa menjelajah alternatif-alternatif yang dapat membuat pandangan-pandangan menjadi nyata. (Ketut Sri Diniari, 2017)

Eksistensialis memiliki pandangan bahwa tugas utama bagi konselor adalah menjelajah persoalan-persoalan yang memiliki kaitan dengan ketidakbermaknaan, ketidakberdayaan, keputusasaan, dan juga kekosongan eksistensial. Menghadapi permasalahan ketidakbermaknaan serta membantu klien membuat makna dari dunia yang kacau adalah tugas yang diemban dalam proses terapeutik. Frankl menekankan bahwa fungsi konselor adalah mengungkapkan bahwa klien mampu menemukan makna hidupnya bahkan dari penderitaannya dan bukan menyampaikan apa makna hidup yang harus dicapai oleh klien. Karena manusia bisa mengubah penderitaan menjadi prestasi melalui sikap yang diambilnya dalam menghadapi penderitaan tersebut. (Pasmawati, 2015)

\section{g. Teknik Dalam Logoterapi}

Dalam proses menganalisis dan membina masalah klien konseling logoterapi juga memiliki teknik khusus sebagaimana konseling pada umumnya. Terdapat tiga teknik yang ada pada logoterapi yaitu: (Pasmawati, 2015)

1) Persuasif

Teknik persuasif merupakan teknik yang membantu klien untuk menghadapi kesulitannya dengan sikap yang lebih konstruktif. Contohnya seperti kasus yang telah disebutkan diatas adalah seorang anak putus sekolah yang mengalami external locus of control sehingga menjadikan dia pasrah terhadap nasib dan cenderung menyandarkan harapannya kepada orang lain tanpa adanya keinginan untuk mengubah keadaannya tersebut. Maka dalam hal ini klien disuruh untuk berjuang untuk menentukan nasibnya dan mewujudkan harapannya sendiri tanpa bergantung dengan orang lain. Artinya klien harus menghadapi dan bukan pasrah terhadap hal tersebut.

2) Paradoxical-intention

Teknik paradoxical intention memanfaatkan kemampuan dalam mengambil sikap dan kemampuan mengambil jarak (self-detachment) terhadap 
keadaan diri sendiri dan lingkungan. Teknik ini cocok untuk pengobatan jangka pendek contohnya seperti remaja putus sekolah yang tidak percaya diri dalam bergaul. Remaja putus sekolah yang tidak percaya diri dalam bergaul biasanya terlalu memandang hal negatif yang mereka kira ada dalam dirinya sehingga tidak menyadari sisi positif yang ada dalam diri mereka.

Dengan teknik ini klien diajak untuk menekan rasa tidak percaya dirinya dan bukan menghilangkannya agar klien sadar dengan rasa tidak percaya dirinya terseut tidak rasional. Teknik ini menguatkan rasa tidak percaya diri tersebut dan ketika klien sadar akan bahwa rasa pecaya dirinya itu tidak rasional dan ia akan mengembangkan kemampuan untuk melawan rasa tidak percaya dirinya.

3) De-reflection

Teknik de-reflection ini memanfaatkan kemampuan transendensi diri (selftranscendence) yang dimilki oleh setiap orang dewasa. Setiap orang dewasa memiliki kemampuan untuk tidak lagi memperhatikan dan kemudian membebaskan diri dari kondisi yang membuatnya tidak nyaman dan mampu mengalihkan perhatiannya kepada hal-hal yang bermanfaat baginya.

Gambaran mengenai teknik ini adalah ketika klien dihadapkan pada situasi yang sulit seperti dalam kasus ini adalah remaja yang mengalami putus sekolah sehingga timbul rasa kecewa dan patah semangat karena terpaksan harus keluar dari sekolah padahal ia masih ingin bersekolah. Dalam hal ini klien dibantu untuk menemukan hikmah dari peristiwa yang dialaminya sampai klien benar-benar menyadari hikmah dan bisa berpikir positif dari peristiwa yang menimpanya tersebut.

\section{h. Langkah-langkah Dalam Konseling Logoterapi}

Masa depan dan makna hidup merupakan orientasi dari konseling logoterapi sebagai tujuan hidupnya. Hubungan pribadi yang diikuti dengan keterbukaan dan keakraban, serta sikap untuk saling memahami, menghargai, dan menerima sepenuhnya satu sama lain adalah relasi yang dibangun antara konselor dan konseli yang disebut sebagai encounter. Proses konseling logoterapi terdapat empat tahap, yaitu: (Jayanti, 2019)

1) Pertama, tahap perkenalan dan pembinaan raport atau tahap pembentukan emosional yang nyaman antara konselor dan konseli. Pada tahap pertama konselor dan konseli akan menciptakan suasana yang nyaman untuk melaksanakan konseling dengan pembinaan raport yang semakin lama akan membuka peluang kepada sebuah encounter. Ketulusan hati, penghargaan terhadap sesama manusia dan pelayanan adalah inti dari encounter.

2) Kedua, tahap penjajakan masalah. Pada tahap kedua ini konselor akan mulai melakukan wawancara konseling kepada klien tentang masalah yang sedang 
dihadapinya. Konselor akan mencoba menggali masalah tersebut dan klien sejak awal diarahkan agar menghadapi masalah tersebut sebagai kenyataan. Karena pada kasus ini adalah remaja putus sekolah, maka konselor akan menggali tentang bagaimana kasus putus sekolah ini bisa menjadi masalah baginya sehingga konselor akan berperan untuk menyadarkan klien bahwa dengan adanya masalah tersebut artinya kita dibimbing menjadi manusia yang lebih kuat serta mampu mengambil keputusan yang tepat melalui penerimaan kita terhadap kenyataan dan jalan yang terbaik adalah dengan menghadapi masalah tersebut.

3) Ketiga, tahap pembahasan bersama. Pada tahap ketiga ini konselor bersama dengan konseli menyamakan persepsi terhadap masalah. Hal bertujuan agar konseli menemukan makna hidup walaupun dalam sebuah penderitaan. Tahap ketiga ini merupakan langkah awal dalam menyelesaikan masalah yang sedang dihadapi konseli. Pada tahap ini konselor akan terus mendorong konseli agar terus bangkit sehingga konseli akan merasa bahwa kemunculan masalah tersebut adalah sebuah kewajaran yang harus diterima dan diambil pelajaran sampai ia bangkit dengan kondisi yang tak lagi sama seperti dahulu.

4) Keempat, tahap evaluasi dan penyimpulan. Setelah melalui proses konseling selama beberapa kali pertemuan, maka langkah selanjutnya adalah evaluasi dan penyimpulan yang akan memberikan kesan apakah ada perubahan pada diri klien setelah melalui proses konseling atau masih sama seperti di awal pertemuan. Pada tahap keempat ini koselor akan menentukan apakah proses konseling akan terus berlanjut atau telah selesai.

\section{i. Kelebihan dan Kekurangan Konseling Logoterapi}

Konseling logoterapi memiliki kelebihan dalam mengajarkan bahwa terdapat maksud, tujuan, dan makna yang harus dicari dan dipenuhi pada setiap individu. Jika kita berhasil menemukan sebab yang dapat mendedikasikan eksistensi kita maka akan kehidupan tidak akan terasa menjadi kosong. (Ketut Sri Diniari, 2017)

Konseling logoterapi memiliki kekurangan ketika ada beberapa klien yang tidak dapat menemukan makna hidupnya sehingga timbul kebosanan yang muncul dari ketidakmampuan seseorang untuk membangkitkan minat apatis, hampa, perasaan tanpa adanya makna, merasa kehilangan tujuan dari hidup, bahkan meragukan kehidupan. Hal ini akan menyulitkan konselor dlaam melakukan terapi pada klien tersebut. Dan logoterapi sulit menguji reabilitas dan validitasnya dengan riset empiris, hal ini dikarenakan bahwa nyaris tidak mungkin mengukur sejumlah persepsi abstrak seperti isolasi eksistensial, kehendak tentang eksistensi, serta ketakutan atas kematian. Bagi klien yang tidak terbiasa menggunakan pemikiran yang abstrak dapat mengalami 
kesulitan untuk mengapresiasi dan mengasimilasi ideal filosofis yang dibutuhkan untuk progresi ke arah kesejahteraan. (Ketut Sri Diniari, 2017)

\section{SIMPULAN}

Berdasarkan uraian yang telah disebutkan diatas maka dapat kita simpulkan bahwa setiap manusia pasti memiliki masalah yang ia hadapi dalam hidupnya tak terkecuali anak atau remaja putus sekolah. Anak atau remaja yang mengalami putus sekolah akan menjumpai berbagai macam masalah seperti timbul kecewa, pasrah terhadap nasibnya dan cenderung bergantung kepada orang lain tanpa adanya keinginan untuk mengubah hal tersebut. Untuk itu konseling logoterapi akan membantu mereka dalam menyadari potensi dan sumber daya spiritual yang selama ini terhambat dalam diri mereka yang kemudian kedua akan mereka manfaatkan untuk menghadapi berbagai macam masalah.

Konseling logoterapi juga akan membantu mereka dalam mencari dan menemukan hikmah dari masalah yang sedang mereka hadapi yang akan membuat mereka sadar bahwa sebenarnya mereka sedang dibimbing menjadi manusia yang kuat dan mampu mengambil keputusan yang tepat sehingga mereka bisa mengubah masalah tersebut menjadi sebuah prestasi melalui sikap yang mereka ambil dalam menghadapinya dan mendapati kehidupan yang terarah.

Viktor Emil Frankl telah menerapkan konseling logoterapi ini ketika dia menjadi tahanan di kamp Jerman. Frankl berhasil meringankan penderitaan para tahanan dengan membantu menunjukkan bahwa terdapat hikmah bahkan di dalam penderitaan sekalipun. Dia melihat langsung bahwa para tahanan yang memiliki ketabahan dan mampu bertahan adalah mereka yang berhasil menemukan dan mengambangkan makna hidupnya dari penderitaan yang dialami. Maka dari itu konseling logoterapi adalah solusi yang tepat bagi remaja yang mengalami putus sekolah dengan menunjukkan kepada mereka bahwa terdapat hikmah bahkan dalam penderitaan sehingga mereka dapat menemukan dan mengembangkan makna dari penderitaan yang mereka alami dan mengubahnya menjadi sebuah prestasi melalui sikap yang mereka ambil.

\section{DAFTAR RUJUKAN}

Albanjari, E. S. (2018). Mengatasi Kenakalan Remaja Pada Masa Transisi. Tadrib, 4(2), 246-259. https://doi.org/10.19109/tadrib.v4i2.24 50

B. Hurlock, E. (n.d.). Psikologi Perkembangan (5th ed.). Jakarta: Erlangga.

Hayati, S. A., \& Aminah, A. (2020). Konseling Logoterapi Untuk Meningkatkan Penerimaan Diri Pada Anak Broken Home. Jurnal Mahasiswa BK An-Nur : Berbeda, Bermakna, Mulia, 6(1), 1-6. https://doi.org/10.31602/jmbkan.v6i1.2 498

Huruswati, I. (2017). Panti Sosial Bina Remaja Naibonat: Tantangan Pendidikan Masa Depan. Sosio Konsepsia, 17(3), 336356. https://doi.org/10.33007/ska.v17i3.835 
Jayanti, N. (2019). Konseling Logoterapi dalam Penetapan Tujuan Hidup Remaja Broken Home. KONSELI : Jurnal Bimbingan Dan Konseling (E-Journal), 6(1), 75-82.

https://doi.org/10.24042/kons.v6i1.420 3

Ketut Sri Diniari, N. (2017). Logoterapi Sebuah Pendekatan Untuk Hidup Bermakna (RSUP Sanglah Denpasar). RSUP Sanglah Denpasar. Retrieved from https://simdos.unud.ac.id

Pasmawati, H. (2015). Pendekatan Logoteraphy Dalam Konseling. Jurnal Ilmiah Syi'ar, 15(1), 53-64.

Riyadiningsih, H., \& Astuti, R. P. (2013).

Kondisi Psikologis Anak Putus Sekolah. Sustainable Competitive Advantage (SCA), 3(1). Retrieved from http://www.jp.feb.unsoed.ac.id/index.p $\mathrm{hp} / \mathrm{sca}-1 /$ article/view/214

Tamba, E. M., Krisnani, H., \& Gutama, A. S. (2015). Pelayanan Sosial Bagi Remaja Putus Sekolah. Prosiding Penelitian dan Pengabdian kepada Masyarakat, 2(2). https://doi.org/10.24198/jppm.v2i2.135 29

Trisnawati, J.-, Nauli, F. A., \& Agrina -. (2014). Faktor-Faktor yang Mempengaruhi Perilaku Agresif Remaja di Smk Negeri 2 Pekanbaru (Journal:eArticle, Riau University). Riau University. Retrieved from https://www.neliti.com/publications/18 7023/faktor-faktor-yangmempengaruhi-perilaku-agresifremaja-di-smk-negeri-2-pekanbar

Wahyuni, S. (2018, November 16). Konseling Logoterapi Sufistik Untuk Meningkatkan Penyesuaian Diri Pada Remaja Terlantar Putus Sekolah Di Upt Pelayanan Sosial Bina Remaja Blitar [Skripsi]. http://repo.iaintulungagung.ac.id/9809/10/DAFTAR\% 20PUSTAKA.pdf 